\title{
What lesson for mine closure we can learn from unassisted soil and ecosystem development
}

\author{
J Frouz Charles University, Czech Republic
}

\begin{abstract}
We used chronosequences of post-mining sites combined with long-term observation of individual sites to compare soil and ecosystem development in post-mining sites undergoing unassisted ecosystem development, and sites reclaimed by various reclamation technologies in different climatic conditions. Using these approaches that allow comparison of individual trials over long periods of time is essential, as in many cases early stage ecosystem development may not be a good indicator of long-term trends. Here, the overview of major mechanisms that determine soil formation and ecosystem development in various climatic conditions are given. We also explore soil formation under various restoration technologies. In suitable climatic conditions, on no toxic overburden, spontaneous processes have the potential to produce valuable ecosystems. In many types of landscapes, namely those with intensive agriculture such as the many parts of Europe, spontaneous recovery of post-mining sites brings a unique opportunity to restore natural habitats. Post-mining landscapes have very high potential for soil carbon sequestration, and in suitable situations, soil formation can be rapid, resulting in development of $10 \mathrm{~cm}$ deep A horizon in several decades. Studies of spontaneous processes can be useful for improving reclamation technologies, namely the selection of proper target vegetation and reconsidering or modification of some operations during reclamation.
\end{abstract}

\section{Introduction}

Mining causes the severe disturbance of ecosystems, particularly during open cast operations where large areas of land are obliterated, by being either mined out or covered by waste rock or tailings. In many places, however, spontaneous re-growth of vegetation has occurred on post-mining land (Prach et al. 2001; Frouz et al. 2008; Mudrák et al. 2010; Pietrzykowski 2008; Skousen et al. 1994; Dickinson et al. 2016). The study of these situations may by interesting for several reasons. We may ask if the sites developing by succession possess any specific quality for which we may want to allow succession in some post-mining sites. Comparing reclaimed sites and succession sites gives us an idea about the effect of our restoration measures (how much they speed up ecosystem development in comparison with situation we would do nothing). Finally deeper insight in to succession and comparing individual processes in succession and reclaimed sites may inspire improvement of existing reclamation technologies. The likelihood of succession and the outcome of its comparison with various reclamation measures depends on many factors such as climatic condition, substrate and the nature of restoration. This paper examines the successional development of an ecosystem with reclamation technologies and focusses on the lessons we can learn, namely, in the selection of proper target vegetation and the modification of some reclamation approaches. There will be particular focus on soil development as successful recovery of soils is basic precondition for restoring functional ecosystems (Frouz et al. 2001; Tibbett 2010; Spain et al. 2015; Spain \& Hollingsworth 2016).

\section{Succession}

Ecological succession describes processes that allow the natural reestablishment of ecosystems after disturbance. Individual organisms gradually migrate to the disturbed area; some establish themselves and interact with other colonies. Beside interaction between organisms, the organisms also alter abiotic environment. Altered environmental conditions in turn affect species migration, establishment, competition and other interaction between species. Plant succession is determined mainly by abiotic site conditions, the species pool and interspecific competition (Glenn-Lewin et al. 1992). However, complex 
interaction between various trophic levels proved to strongly effect community organisation and ecosystem development during succession (De Deyn et al. 2003; Frouz et al. 2008; Thompson et al. 1993). During succession, the overall carbon and nitrogen stocks in the ecosystem gradually increased as they are accumulated via biological processes from the atmosphere. On the other hand, some rock derived elements, namely $\mathrm{P}$, but also $\mathrm{Ca}, \mathrm{Mg}$ (and others), are gradually transferred into the biomass. This is closely related to soil changes that largely determine ecosystem changes (Frouz et al. 2008). It is generally accepted that vegetation changes during succession are crucial for the successional development of an ecosystem, including soil formation. Plants can affect soil directly or they can modify the soil biota community which in turn may effect soil formation and plant growth (Frouz et al. 2008). Beside roots, plant litter forms the bottom of the food web and also plays a principal role in the formation of the physical structure of the habitat by the organic matter entering the soil. The organic matter entering the soil affects soil biota that feeds directly or indirectly on that litter. Soil biota affects the rate of organic matter decomposition and nutrient re-release which in turn affects nutrient availability. Soil biota also affects the distribution of organic matter and aggregate formation which in turn affects sorption capacity and the water holding capacity of soil. All this affects soil formation and modifies the soil as a habitat for plants (Ma et al. 2003; Makulec 2002; Scheu \& Parkinson 1994; Thompson et al. 1993). In soil poor with nutrients, plant conserve most of the nutrients in their body; they have evergreen foliage with thick leaves or needles that produces litter with low nutrient content and low decomposability. Decomposition of such litter is slow, bioturbation effect of fauna is low, and most of the litter is slowly decomposed on soil surface. In this way developed humus form caled mor. If the soil contains nutrients, plants have thin leaves with high turnover and higher nutrient content. Soil is supplied by easy decomposable litter with low carbon to nitrogen $(\mathrm{CN})$ ratio. Litter decomposition is fast and intensive soil fauna bioturbation results in the incorporation of litter into soil. This resulted in formation of humus form called mull (Frouz \& Tajovsky 2007; Frouz et al. 2008; Ponge 2003). Level of bioturbation and resulting humus form are also related to the composition of soil biota communities. The low $\mathrm{CN}$ ratio and mixing of the organic layer into the mineral soil promotes a low fungal bacterial ratio, while high $\mathrm{CN}$ ratio and accumulation of litter on the soil surface promotes a high fungal bacterial ratio (Frouz et al. 2008, 2009, 2013a, 2013b; Ponge 2003). This corresponds to the degree of higher $\mathrm{N}$ immobilisation in high $\mathrm{CN}$ ratio, and vice versa $\mathrm{N}$ mineralisation in low $\mathrm{CN}$ ratio (Figure 1 ). This clearly shows that besides the dominant role of vegetation soil biota, including soil fauna, ecosystem engineering is essential for post-mining soil development (Boyer \& Wratten 2010).

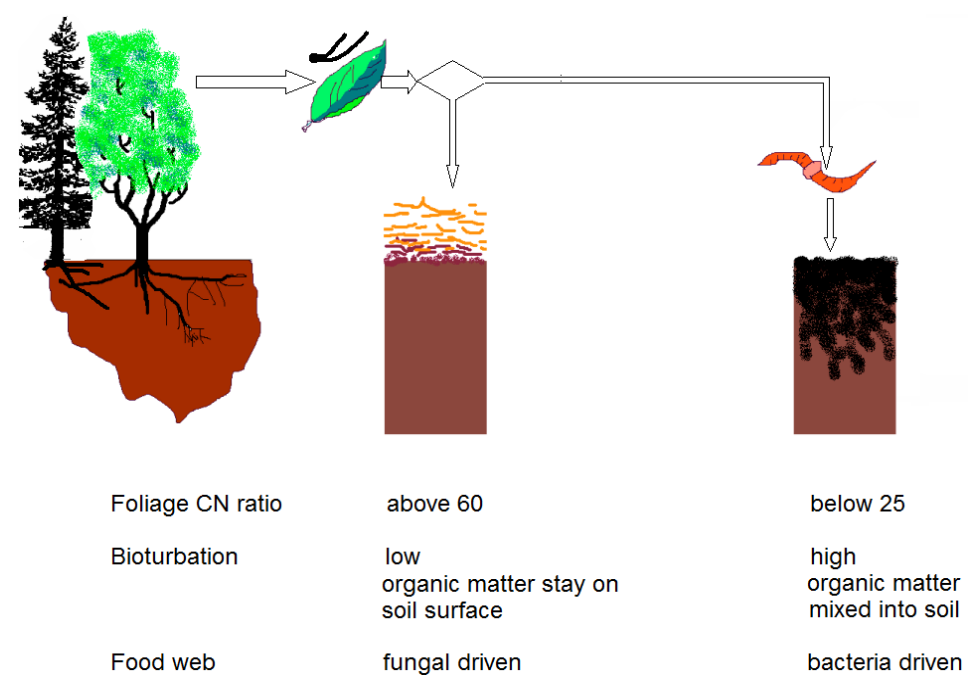

Figure 1 This conceptual model describes the relationships between the tree effect and fauna effect on soil properties. Carbon to nitrogen (CN) ration (dimensionless) of foliage, level of bioturbation and type of foodweb is given. When the fauna effect is small, litter tends to remain on the soil surface, when the Oe horizon is thick, the A horizon is thin, microbial respiration is high, and soil $C$ storage is low, the food web is mostly fungal driven. When the fauna effect is large, litter tends to be transported into the soil, and the Oe horizon is thin, the A horizon is thick, microbial respiration is low, and soil C storage is high and the food web is mostly bacterial driven 
When we compare soil and ecosystem development in reclaimed and unreclaimed sites we can see in parameters, such as the thickness of A horizon accumulation of soil organic matter, development of plant biomass and others that, in young reclaimed sites the recovery of these parameters is much faster during the 10-15 years of ecosystem development. However, when we compare sites which are 20 years or older the differences disappear and/or succession sites reach higher values than that of the reclaimed sites (Frouz et al. 2001, 2008, 2015a), (Figure 2). This highlights needs for long-term observation of post-mining sites, as ecosystem development shortly after establishment may not be a good indicator of long-term trends.

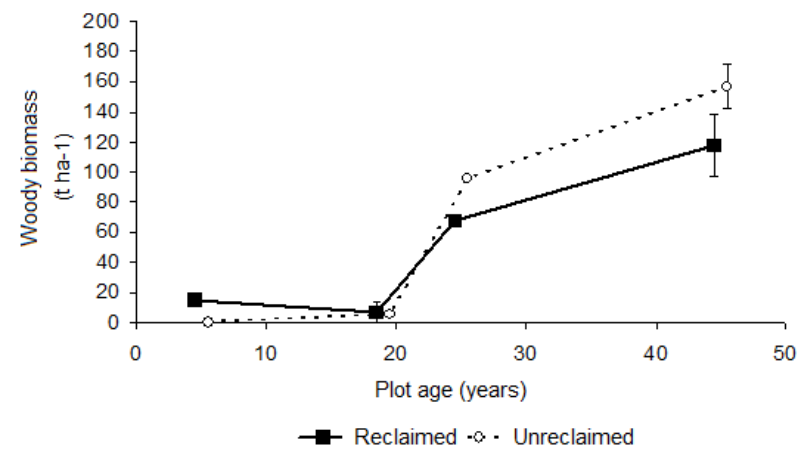

(a)

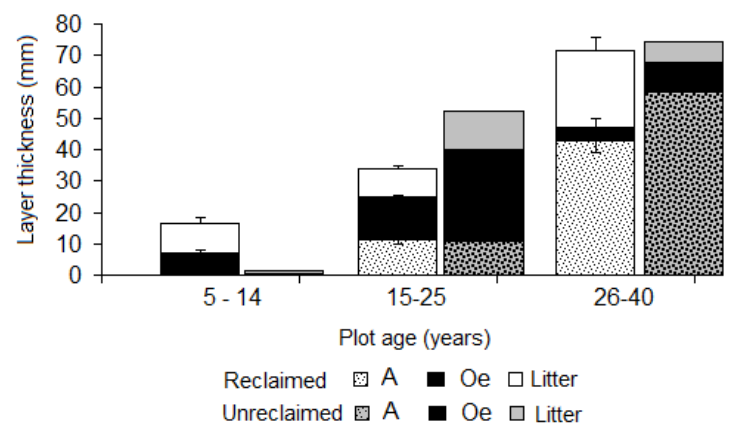

(b)

Figure 2 (a) Development of woody biomass, and (b) thickness of top soil layers, in reclaimed alder plantation and unreclaimed sites overgrown by spontaneous succession in post-mining sites near Sokolov (Czech Republic), based on (a) Frouz et al. 2015a and (b) Frouz and Tajovsky 2007

Most sites demonstrating achievable successional development of ecosystems come from a temperate climate, which were on non-toxic soil, and where overburden was kept rough and loose after dumping (Prach et al. 2001; Broring \& Wiegleb 2005; Frouz et al. 2008; Tropek et al. 2010, 2012; Frouz \& Franklin 2015).

Numerous studies, generally conducted in Europe, also conclude that post-mining sites, mainly unreclaimed ones overgrown by succession, may harbour a large number of endangered species in the surrounding landscape (Prach et al. 2001; Broring \& Wiegleb 2005; Tropek et al. 2010, 2012). This mainly occurs in situations where intensive agriculture substantially decreases diversity of surrounding landscapes. In such situations post-mining sites, which are less supplied by nutrients and offer the variety of specific habitats, may serve as a refuge for many rare species. In such instances it is clearly wise to use the opportunity and allow succession to create a new wilderness, or at the very least, a valuable replacement habitat for rare and endangered species. However, it should be emphasised that this applies to cultural landscapes where diversity is already reduced by agriculture and other human activities.

\section{Succession versus major reclamation approaches}

In many cases, post-mining sites are heaped in such a way resulting in a terrain with a wavelike appearance. These waves promote the appearance of spatial heterogeneities in the soil's physical and chemical properties, e.g. by washing clays and ions downhill (Frouz et al. 2011). Some of the heterogeneity is even apparent after levelling. Levelling enables a site to become more homogeneous in terms of soil physics and chemistry, as well as more logistically accessible for machinery that later can bring seeds, seedlings, fertiliser etc. However, the initial heterogeneity may prove beneficial. For example, seeds of air-born species can be trapped on the leeward side of these waves, and the establishment of air-born trees and shrubs may fare much better in wave-like terrain than in levelled sites (Frouz \& Velichová 2011). Heterogeneity can also promote specific microsites with faster soil development (Topp et al. 2001). On the other hand, levelling may cause soil compaction which may tend to support grasses and suppress the tree growth (Ashby 1997). The benefits of levelling are likely to prevail if topsoil is applied and if the site is 
dedicated to agricultural production or the restoration of a grassland-dominated ecosystem. For forest restoration risks and the benefits of levelling, sites should be evaluated on a case-by-case basis.

Minimisation of surface heterogeneity can be both an advantage and a disadvantage, as it eliminates many microhabitats that would allow a more rapid establishment of woody vegetation, and faster soil development in unreclaimed sites (Topp et al. 2001).

The advantages and benefits of substrate levelling need to be carefully evaluated for local conditions and in exploring possible new technologies. These may include techniques that allow substrate levelling with a minimal compaction or heaping materials in such a way that results in a surface which can be used for planting, and also offer a level of spatial heterogeneity.

The application of topsoil substitutes, or even more complex covers consisting of several layers, is a very complex reclamation approach. This operation instantly improves soil condition and allows for a rapid establishment of highly productive vegetation (Boruvka et al. 2012; Rohoskova et al. 2006). It may increase primary productivity to a level that could be reached naturally after decades or even centuries. Application of topsoil or topsoil substitutes is irreplaceable in restoring agricultural land or in restoring extreme, specific toxic substrates. The more complex cover is often used with the bottom layer consisting of clay or gravel, which separates the toxic layer from the fertile topsoil placed on top. Topsoil spreading is a costly operation and, besides the clear advantages mentioned above, it may also bring some disadvantages; soil spreading may promote soil compaction and the release of nutrients. Compaction may also negatively affect the rooting of plants, especially trees (Ashby 1997, 1998). The release of nutrients may support grasses and promote the competition of grasses over trees (Ashby 1997). Several studies also have shown lower plant diversity on topsoil sites in comparison with sites either without topsoil or with reduced topsoil applications (Bowen et al. 2005; Prach 1987). The effect of topsoil may be closely connected with the technologies used, which may vary from direct transfers of undisturbed soil blocks, including associated vegetation, to removing topsoil, stockpiling and then spreading it. The transfer of undisturbed blocks gives excellent results in ecosystem recovery, but it represents an extremely costly and logically complex operation (Boyer et al. 2010). Other techniques are associated with the disturbance of the soil structure during soil handling (Boyer et al. 2010). Furthermore, the stockpiling of topsoil causes the formation of anaerobic conditions in the pile, which may lead to eradication of soil fauna and changes in the soil microbial community. Changes in the microbial community during stockpiling and spreading may lead to a loss of organic matter and future degradation of the soil structure (Ingram et al. 2005; Wick et al. 2009). These effects are more severe in the deeper layers of the stockpile, and may potentially be lessened by a reduction of stockpile heights to under 2-3 m (Boyer et al. 2010). Development of more conservative and economically sound methods of topsoil application, plus a combination of different approaches, as well as a careful evaluation of the topsoil for particular future uses of post-mining landscapes, represent a promising field for future research.

The introduction of seeds or seedlings is a basic restoration technique that speeds up succession and soil development. Planted vegetation affects soil development, especially litter qualities such as the $\mathrm{CN}$ ratio. Soil development and C soil storage may not closely correlate with the above-ground production or litter input (Frouz et al. 2008). Trees which produce easily decomposable litter promote higher carbon storage and faster A horizon formation inputs (Frouz et al. 2008). On sites with trees producing litter with a low CN ratio (the deciduous species), the organic Oe layer was narrow or absent and a thick organomineral A layer was evident. On sites with trees producing litter with a high $\mathrm{CN}$ ratio (the evergreen species), in contrast, a thick Oe layer and a thin A layer were evident.

Besides $\mathrm{CN}$ ratio, earthworm abundance and earthworm bioturbation activity are the strongest predictors of $A$ layer thickness and $C$ accumulation in the mineral topsoil. The greatest effect of trees on soil may be indirect, i.e. may result from the effect of tree litter on the bioturbation activity of soil fauna. Bioturbation changes not only the biomass and activity of microorganisms but also the composition of the soil microbial community. When soil fauna are not abundant, most organic matter resides in litter and in the Oe horizon. When soil fauna is abundant, most organic matter is moved into the mostly mineral A horizon. This shift 
substantially changes the conditions for microbial activity and may be an important driver of microbial activity (Frouz et al. 2013a).

However, trees affect site development over the long-term, for example beech (Fagus silvatica) seedlings are more successful on unreclaimed sites covered by willow and birch than on alder plantations (Frouz et al. 2015b). The alder plantations are generally assumed to be beneficial for soil development as a nitrogen fixer. Accumulation of nitrogen in the ecosystem drives the speed of succession and ecosystem recovery. Nevertheless, this example shows that one should be careful, as adding too much nitrogen may change the succession trajectory, rather than speeding up the existing one.

\section{$4 \quad$ Effect of substrate}

We still do not have enough comprehensive information to draw an overall pattern on how post-mining site succession depends on substrate. This section focuses on substrate properties that may be most adverse for successional ecosystem development in post-mining sites. Post-mining substrates (overburden) show apparent differences from recent soils (Bradshaw 1993, 1997). Overburden typically do not have soil aggregates as we know it from recent soils, they often have extreme texture (e.g. too much sand and gravel or too much clay), substrate can repel water (hydrophobic) and may be toxic for plant and soil biota for various reasons. Pyrite weathering, commonly occur, which decrease $\mathrm{pH}$. Low pH increased mobility of some heavy metals, as well as other toxic elements in the soils (Bradshaw 1993; Frouz et al. 2005; Jener \& Janssenmommen 1993; Sample \& Suter 2002). The high content of salts, is another reason for toxicity of post-mining sites (Frouz et al. 2005). Overburden toxicity can be estimated using biological tests or chemical analysis of the soil. The $\mathrm{pH}$ is useful and affordable parameters to measure to indicate toxicity: sites with a pH below 3.5 are very likely to be toxic; sites with pH below 5.5 should be tested for potentially toxic elements (As, Se etc.). Sites close to a neutral or slightly alkaline are usually suitable but should be checked for conductivity to exclude salinity problems (Frouz et al. 2005), (Figure 3). In some cases toxicity problems such as high salt content may not appear in freshly excavated overburden but rather later during weathering. The texture of the overburden may by dominated by a few grain sizes due to the material separation in geological time. Here successional development of ecosystems is particularly slow in the substrates consisting from slowly weathering stones and gravel (Rydgren et al. 2013). Clay substrates, on the other hand, have a higher water holding capacity and cation exchange capacity and usually more nutrients (Sourkova et al. 2005). In these substrates soil development may be fast. For example in some unreclaimed soils, a $10 \mathrm{~cm}$ deep A horizon can develop within 40 years. But on the other hand nutrient availability may cause problems, in some cases namely in forest restoration when grass tree competition become more severe as nutrient content increases.

Clay soils may also suffer from unsuitable soil structure which results in poor drainage (Scullion \& Malik 2000). However, quite often clay-rich overburden have form of shales or mudstones, where the clay is more or less consolidated and impregnated either with carbonates or various types of organic matter such as kerogen (Kŕíbek et al. 1998). As a result of this only a small fraction of such materials disintegrates into physical clay during the weathering. The bulk of the mudstones disintegrates into silt or sand size fragments which result in suitable soil texture. For example, Kuráž et al. (2012) show that in mudstones which contain 70 per cent clay most of that clay can be bounded by carbonates and kerogen into clay-rich concretions and only 16 per cent of the clay was released by material weathering during 50 years. The effect of adverse substrate may be enhanced by unsuitable climatic conditions, namely by dry or cold climates where soil development is very slow. 


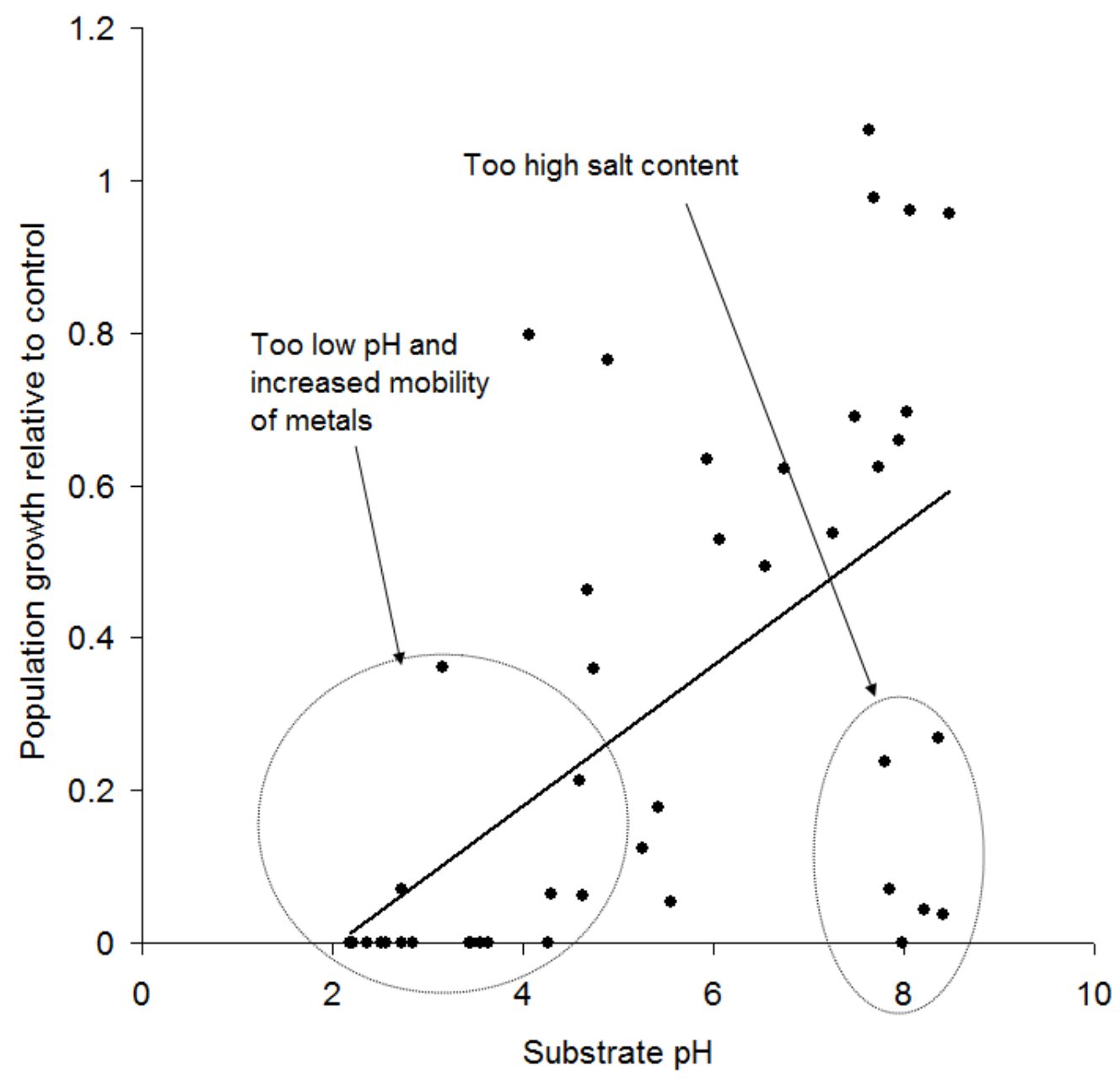

Figure 3 Population growth of potworm Enchytraeus crypticus in overburden substrates of various $\mathrm{pH}$ in laboratory tests. Population growth is expressed in relation to control meadow soil (control soil would have vale 1), based on Frouz et al. 2005

\section{$5 \quad$ Effect of climate}

We are still far from understanding how the post-mining ecosystem development handles various climatic conditions and how the effect of individual reclamation measures vary with climatic conditions. This section explores the effect of climate on ecosystem development and particular reclamation technologies.

It has been mentioned that trees that produce litter with low $\mathrm{CN}$ ratio support intensive bioturbation which yield in C accumulation in the soil and fast C storage (Frouz et al. 2009, 2013a). However, extensive metaanalysis (Vinduskova \& Frouz 2013) shows that this pattern may vary with climate. The rate of soil organic matter accumulation in sites planted with conifers tend to be higher in colder climate. The opposite is true for sites with grasslands. Soil organic matter accumulation under deciduous forests show no significant correlation with temperature (Figure 4). This relationship between temperature, soil organic carbon (SOC) storage, and vegetation type corresponds with the natural distribution of grassland, coniferous forest, and deciduous forest (Brown \& Gibson 1983). This indicates that for reclamation of post-mining sites, the planted vegetation should be typical for the particular biome in which the postmining site occurs. In other words, grasses should be planted at warmer sites, conifers at colder sites, and deciduous trees at intermediate sites. 


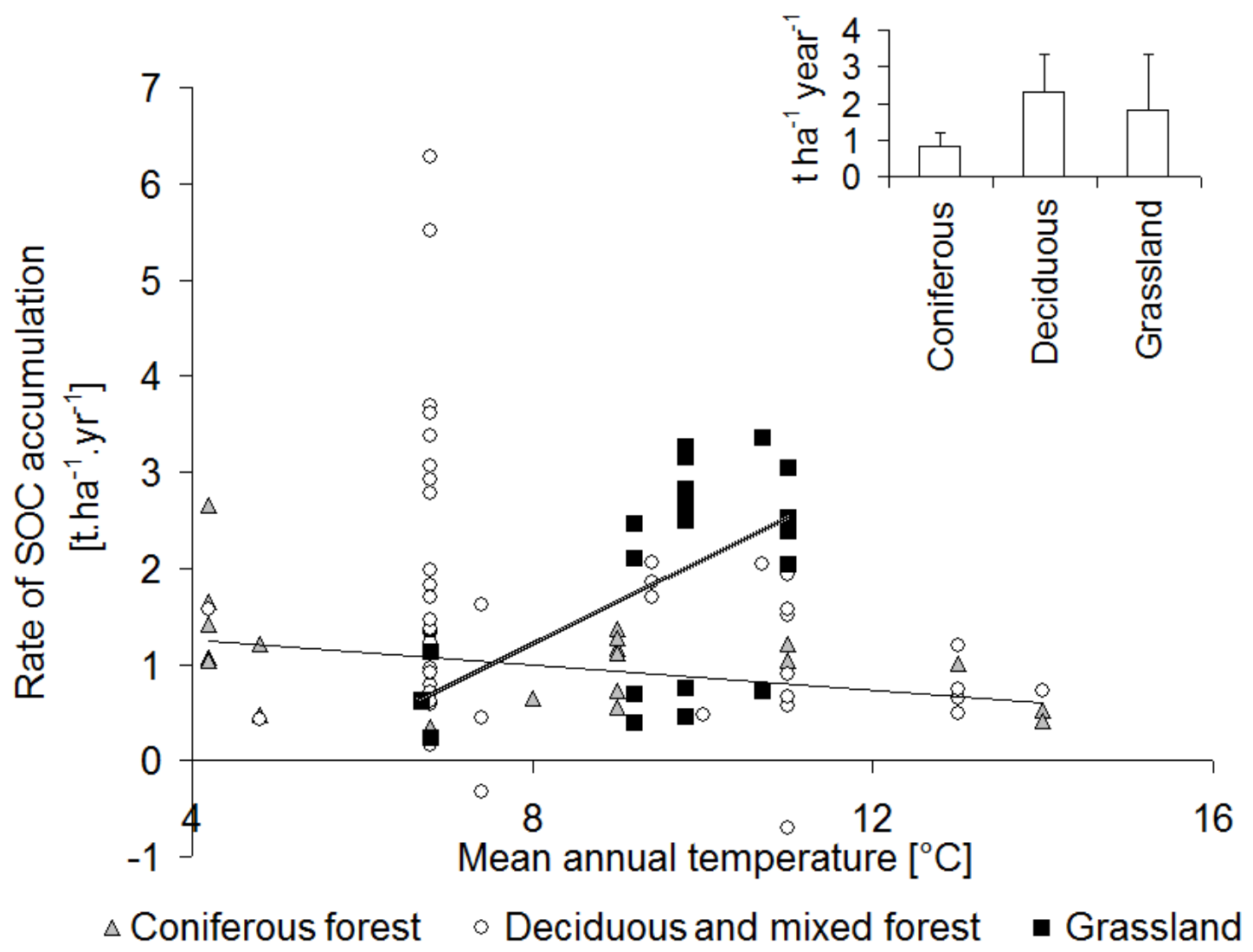

Figure 4 Sequestration of soil organic matter in post-mining sites in the northern hemisphere in relation to the type of vegetation used in reclamation and mean annual temperature, mean value for individual types of vegetation are in the inserted bar graph, based on Vindušková and Frouz, 2013

Another example of how the speed of recovery and the effect of individual reclamation techniques vary with climate is illustrated by the comparison of post-mining sites recoveries in the southeast to northwest gradient across USA, in four post-coal mining areas: Tennessee (TN), Indiana (IN), Illinois (IL), and Wyoming (WY). The higher temperature mean annual temperature/annual precipitation was $14.1^{\circ} \mathrm{C} / 1,092 \mathrm{~mm}$ in the southeast and the lowest in the northwest $6.7^{\circ} \mathrm{C} / 380 \mathrm{~mm}$. Climax vegetation was represented by hardwood forest (TN and IN) or by tall grass prairie (IL), in the eastern part of gradient, and by shortgrass prairie in the western part (WY) (Table 1). The shortgrass prairie soil community contained abundant root-feeding organisms which may establish quicker than the more saprophagous soil biota that was abundant at the other sites. There was almost no apparent succession of the soil community on post-mining sites in the shortgrass prairie ecosystem of WY. Even the young restoration sites were closer to the climax stage in shortgrass chronosequence than in the other chronosequences - in contrary to eastern sites where more complex succession development was observed. In eastern chronosequences, heading towards forest and tallgrass prairie bioturbation played an important role in topsoil formation. This resulted in a complex soil profile development compared. In the contrary, the restored shortgrass prairie did not have many changes, in the soil profile, happen after topsoil application. This may contribute to faster recovery communities in shortgrass prairie in comparison with tall grass prairie and forest (Frouz et al. 2013c). In agreement with requirements of Surface Mining Control and Reclamation Act (SMCRA), topsoil or topsoil substitutes were applied in the reclaimed sites. When we compare soil recovery in reclaimed and unreclaimed sites, contrasting results were observed in the eastern and western states. In the eastern part of USA there was no or little difference in the development of reclaimed and unreclaimed forest sites (Frouz \& Franklin 2015). In these sites, extensive compaction associated with site preparation during restoration measure may negatively affect the development of a forest ecosystem (Ashby 1998). In contrary to the shortgrass prairie in Wyoming where reclaimed sites with topsoil application approach very quickly to climax, there is little or no development of soil and soil biota communities in unreclaimed sites. This indicates that topsoil 
application is essential to the restoration of grassland ecosystem in dry climates. While restoring forest in wet conditions, the benefits of reclamation may be less pronounced.

Table 1 Comparison of development in various post-mining sites along the climatic gradient across the USA (Frouz et al. 2013c)

\begin{tabular}{|c|c|c|}
\hline Parameter & Wet sites in eastern USA & Dry sites in western USA \\
\hline Climatic condition & $14.1^{\circ} \mathrm{C} / 1,092 \mathrm{~mm}$ & $6.7^{\circ} \mathrm{C} / 380 \mathrm{~mm}$ \\
\hline Climax vegetation & Deciduous forest or tallgrass prairie & Shortgrass prairie \\
\hline Soil food web & Complex, mostly based on plant litter & $\begin{array}{l}\text { Simpler, mostly derived from } \\
\text { root and root exudates }\end{array}$ \\
\hline $\begin{array}{l}\text { Invertebrate soil } \\
\text { ecosystem engineers }\end{array}$ & $\begin{array}{l}\text { Feeds of plant/mix litter soil contribute to } \\
\text { the formation of organomineral soil } \\
\text { aggregates and A horizon }\end{array}$ & Create burrows for nesting \\
\hline $\begin{array}{l}\text { Recovery after topsoil } \\
\text { application }\end{array}$ & $\begin{array}{l}\text { Development is complex, goes through } \\
\text { many stages with gradual development of } \\
\text { topsoil layers. Twenty years still differ from } \\
\text { climax but } 40-50 \text { years are similar to climax }\end{array}$ & $\begin{array}{l}\text { Fast } 10 \text { year old site had very } \\
\text { similar soil community as climax }\end{array}$ \\
\hline $\begin{array}{l}\text { Recovery during } \\
\text { succession }\end{array}$ & $\begin{array}{l}\text { Fast, } 40 \text { year old sites are comparable to } \\
\text { reclaimed sites; some parameters may be } \\
\text { even more advanced }\end{array}$ & $\begin{array}{l}\text { Forty year old sites show slow } \\
\text { very little development }\end{array}$ \\
\hline
\end{tabular}

\section{Conclusion}

Successional development of post-mining sites may, in some cases, lead to the development of valuable ecosystems. In many types of landscapes, namely those with intensive agriculture such as many parts of Europe spontaneous recovery of post-mining sites, bring unique opportunities to restore natural habitats. In young sites, the development of succession sites are significantly slower compared to reclaimed sites, but this difference decreases with age. Early ecosystem evaluation may not be a good predictor of long-term ecosystem development. This emphasises the need for more research about the long-term development of post-mining ecosystems. Beside vegetation, soil biota plays a principal role in soil formation and ecosystem development. The post-mining sites have large potential for carbon storage both in soil and biomass. Vegetation close to local climax vegetation may help to maximise this potential. Individual restoration measures may substantially change with climatic conditions. This may be important, not only for transferring reclamation knowledge from one place to another, but also for modifying reclamation practices to adapt to ongoing climatic change.

\section{References}

Ashby, WC 1997, 'Soil ripping and herbicides enhance tree and shrub restoration on stripmines', Restoration Ecology, vol. 5, pp. 169-177.

Ashby, WC 1998, 'Reclamation with trees pre- and post-SMCRA in southern Illinois', International Journal of Surface Mining, Reclamation and Environment, vol. 12, pp. 117-121.

Boruvka, L, Kozak, J, Muhlhanselova, M, Donatova, H, Nikodem, A, Nemecek, K \& Drabek, O 2012, 'Effect of covering with natural topsoil as a reclamation measure on brown-coal mining dumpsites', Journal of Geochemical Exploration, vol. 113, pp. 118-123.

Bowen, CK, Schuman, GE, Olson, RA \& Ingram, J 2005, 'Influence of topsoil depth on plant and soil attributes of 24-year-old reclaimed mined lands', Arid Land Research and Management, vol. 19, pp. 267-284.

Boyer, S \& Wratten, SD 2010, 'The potential of earthworms to restore ecosystem services after opencast mining - A review', Basic and Applied Ecology, vol. 11, pp. 196-203.

Boyer, S, Wratten, S, Pizey, M \& Weber, P 2010, 'Impact of soil stockpiling and mining rehabilitation on earthworm communities', Pedobiologia, vol. 54, pp. 99-102.

Bradshaw, A 1993, 'The reconstruction of ecosystems', Journal of Applied Ecology, vol. 20, pp. 1-17. 
Bradshaw, A 1997, 'Restoration of mined lands - using natural processes', Ecological Engineering, vol. 8, pp. $255-269$.

Broring, U \& Wiegleb, G 2005, 'Soil zoology II: Colonization, distribution, and abundance of terrestrial Heteroptera in open landscapes of former brown coal mining areas', Ecological Engineering, vol. 24, pp. 135-147.

Brown, JH \& Gibson, AC, 1983, Biogeography, C. V. Mosby, Saint Louis.

De Deyn, GB, Raaijmakers, CE, Zoomer, HR, Berg, MP, de Ruiter, PC, Verhoef, HA, Bezemer, TM \& van der Putten, WH 2003, 'Soil invertebrate fauna enhances grassland succession and diversity', Nature, vol. 422, pp. 711-713.

Dickinson, A, Humphries, RN, Pawlett, M, Tibbett, M 2016, 'Ecological and soil development of 19th Century iron and coal mine wastes at Bryn Defaid, South Wales', in AB Fourie \& M Tibbett (eds), Proceedings of the 11th International Conference on Mine Closure, Perth, in print.

Frouz, J \& Franklin, JA 2015, 'Vegetation and soil development in planted pine and naturally regenerated hardwood stands decades after mining', Journal of the American Society of Mining and Reclamation.

Frouz, J, Pizl, V \& Tajovsky, K 2007, 'The effect of earthworms and other saprophagous macrofauna on soil microstructure in reclaimed and un-reclaimed post-mining sites in Central Europe', European Journal of Soil Biology, vol. 43, pp. S184-S189.

Frouz, J, Kalčík, J \& Velichová, V 2011, 'Factors causing spatial heterogeneity in soil properties, plant cover, and soil fauna in a non-reclaimed post-mining site', Ecological Engineering, vol. 37, pp. 1910-1913.

Frouz, J, Keplin, B, Pižl, V, Tajovský, K, Starý, J, Lukešová, A, Nováková, A, Balík, V, Háněl, L, Materna, J, Düker, C, Chalupský, J, Rusek, J \& Heinkele, T 2001, 'Soil biota and upper soil layers development in two contrasting post-mining chronosequences', Ecological Engeneering, vol. 17, pp. 275-284.

Frouz, J, Kristufek, V, Bastl, J, Kalcik, J \& Vankova, H 2005, 'Determination of toxicity of spoil substrates after brown coal mining using a laboratory reproduction test with Enchytraeus crypticus (Oligochaeta)', Water Air and Soil Pollution, vol. 162, pp. 37-47.

Frouz, J, Prach, K, Pižl, V, Háněl, L, Starý, J, Tajovský, K, Materna, J, Balik, V, Kalčík, J \& Řehounková, K 2008, 'Interactions between soil development, vegetation and soil fauna during spontaneous succession in post mining sites', European Journal of Soil Biology, vol. 44, pp. 109-121.

Frouz, J, Pizl, V, Cienciala, E \& Kalcik, J 2009, 'Carbon storage in post-mining forest soil, the role of tree biomass and soil bioturbation', Biogeochemistry, vol. 94, pp. 111-121.

Frouz, J, Liveckova, M, Albrechtova, J, Chronakova, A, Cajthaml, T, Pizl, V, Hanel, L, Stary, J, Baldrian, P, Lhotakova, Z, Simackova, H \& Cepakova, S 2013a, 'Is the effect of trees on soil properties mediated by soil fauna? A case study from post-mining sites', Forest Ecology and Management, vol. 309, pp. 87-95.

Frouz, J, Thebault, E, Pizl, V, Adl, S, Cajthaml, T, Baldrian, P, Hanel, L, Stary, J, Tajovsky, K, Materna, J, Novakova, A \& de Ruiter, PC 2013b, 'Soil Food Web Changes during Spontaneous Succession at Post Mining Sites: A Possible Ecosystem Engineering Effect on Food Web Organization?', PLOS ONE, vol. 8, p. e79694.

Frouz, J, Jilkova, V, Cajthaml, T, Pizl, V, Tajovsky, K, Hanel, L, Buresova, A, Simackova, H, Kolarikova, K, Franklin, J, Nawrot, J, Groninger, JW \& Stahl, PD 2013c, 'Soil biota in post-mining sites along a climatic gradient in the USA: Simple communities in shortgrass prairie recover faster than complex communities in tallgrass prairie and forest', Soil Biology and Biochemistry, vol. 67, pp. 212-225.

Frouz, J, Dvorščík, P, Vávrová, A, Doušoová, O, Kadochová, Š \& Matějíček, L 2015a, 'Development of canopy cover and woody vegetation biomass on reclaimed and unreclaimed post-mining sites', Ecological Engineering, vol. 84, pp. 233-239.

Frouz, J, Voborilova, V, Janousova, I, Kadochova, S \& Matejicek, L 2015b, 'Spontaneous establishment of late successional tree species English oak (Quercus robur) and European beech (Fagus sylvatica) at reclaimed alder plantation and unreclaimed post mining sites', Ecological Engineering, vol. 77, pp. 1-8.

Glenn-Lewin, DC, Peet, RK \& Veblen, TT 1992, Plant Succession. Theory and Prediction, Chapman and Hall London.

Ingram LJ, Schuman, GE, Stahl, PD, Spackman, LK 2005, 'Microbial Respiration and Organic Carbon Indicate Nutrient Cycling Recovery in Reclaimed Soils', Soil Science Society American Journal, vol. 69, pp. 1737-1745.

Jener, H, Janssenmommen, JPM 1993, 'Duckweet Lemna minor as a tool for testing toxicity of coal residues and polluted sediments', Archives of Environmental Contamination and Toxicology, vol. 25, pp. 3-11.

Kř́bek, B, Strnad, M, Boháček, Z, Sýkorová, I, Čejka, J Sobalík, Z 1998, 'Geochemistry of Miocene lacustrine sediments from the Sokolov Coal Basin (Czech Republic)', International Journal of Coal Geology, vol. 37, pp. 207-233.

Kuráž, V, Frouz, J, Kuráž, M, Mako, A, Šustr, V, Cejpek, J, Romanov, OV \& Abakumov, EV 2012, 'Changes in some physical properties of soils in the chronosequence of self-overgrown dumps of the Sokolov quarry-dump complex, Czechia', Eurasian Soil Science, vol. 45, pp. 266-272.

Ma, Y, Dickinson, NM, Wong, MH 2003, 'Interactions between earthworms, trees, soil nutrition and metal mobility in amended $\mathrm{Pb} / \mathrm{Zn}$ mine tailings from Guangdong, China', Soil Biology \& Biochemistry, vol. 35 pp. 1369-1379.

Makulec, G 2002, 'The role of Lumbricus rubellus Hoffm. in determining biotic and abiotic properties of peat soils', Polish Journal of Ecology, vol. 50, pp. 301-339.

Mudrák, O, Frouz, J, Velichova, V 2010, 'Understory vegetation in reclaimed and unreclaimed post-mining forest stands', Ecological Engineering, vol. 36, pp. 783-790.

Pietrzykowski, M 2008, 'Soil and plant communities development and ecological effectiveness of reclamation on a sand mine cast', Journal of Forest Science, vol. 54, pp. 554-565.

Ponge, JF 2003, 'Humus forms in terrestrial ecosystems: a framework to biodiversity', Soil Biology \& Biochemistry, vol. 35, pp. 935-945.

Prach, K 1987, 'Succession of vegetation on dumps from strip coal mining, N.W. Bohemia, Czechoslovakia', Folia Geobotancia, vol. 22, pp. 339-354.

Prach, K, Bartha, S, Joyce, CHB, Pysek, P, Van Diggelen, R \& Wiegleb, G 2001, 'The role of spontaneous vegetation succession in ecosystem restoration: A perspective', Applied Vegetation Science, vol. 4, pp. 111-114. 
Rohoskova, M, Penizek, V \& Boruvka, L 2006, 'Study of anthropogenic soils on a reclaimed dumpsite and their variability by geostatistical methods', Soil Water Research, vol. 1, pp. 72-78.

Rydgren, K, Halvorsen, R, Auestad, I \& Hamre, LN 2013, 'Ecological design is more important than compensatory mitigation for successful restoration of alpine spoil heaps', Restoration Ecology, vol. 21, pp. 17-25.

Sample, BE \& Suter, GW 2002, 'Screening evaluation of the ecological risks to terrestrial wildlife associated with a coal ash disposal site', Human and Ecological Risk Assessment, vol. 8, pp. 637-656.

Scheu, S, Parkinson, D 1994, 'Effects of invasion of an aspen forest (Canada) by Dendrobaena octaedra (Lumbricidae) on plant growth', Ecology, vol. 75, pp. 2348-2361.

Scullion, J \& Malik, A 2000, 'Earthworm activity affecting organic matter, aggregation and microbial activity in soils restored after opencast mining for coal', Soil Biology and Biochemistry, vol. 32, pp. 119-126.

Skousen, JG, Johnson, C \& Garbutt K 1994, 'Natural revegetation of 15 abandoned mine land sites in West Virginia', Journal of Environmental Quality, 23:1224-1230.

Sourkova, M, Frouz, J \& Santruckova, H 2005, 'Accumulation of carbon, nitrogen and phosphorus during soil formation on alder spoil heaps after brown-coal mining, near Sokolov (Czech Republic)', Geoderma, vol. 124, pp. 203-214.

Spain, AV \& Holligsworth, I 2016, 'Selected properties of the incipient soils developing on coal mining wastes, Bowen Basin, Australia', in AB Fourie \& M Tibbett (eds), Proceedings of the 11th International Conference on Mine Closure, Perth, in print.

Spain, AV, Tibbett, M, Hinz, DA, Ludwig, JA \& Tongway, DT 2015, 'The mining-restoration system and ecosystem development following bauxite mining in a biodiverse environment of the seasonally dry tropics of Australia', in M Tibbett (ed.), Mining in Ecologically Sensitive Landscapes, CRC press, pp 159-227.

Thompson, L, Thomas, CD, Radley, JMA, Williamson, S \& Lawton, JH 1993, 'The effect of earthworms and snails in a simple plant community', Oecologia, vol. 95, no. 2, pp. 171-178.

Tibbett, M 2010, 'Large-scale mine site restoration of Australian eucalypt forests after bauxite mining: soil management and ecosystem development', in LC Batty \& KB Hallberg (eds), Ecology of Industrial Pollution, Cambridge University Press, Cambridge, p. 309-326.

Topp, W, Simon, M, Kautz, G, Dworschak, U, Nicolini, F \& Pruckner, S 2001, 'Soil fauna of a reclaimed lignite open-cast mine of the Rhineland: improvement of soil quality by surface pattern', Ecological Engineering, vol. 17, pp. 307-322.

Tropek, R, Kadlec, T, Karesova, P, Spitzer, L, Kocarek, P, Malenovsky, I, Banar, P, Tuf, IH, Hejda, M \& Konvicka, M 2010, 'Spontaneous succession in limestone quarries as an effective restoration tool for endangered arthropods and plants', Journal of Applied Ecology, vol. 47, pp. 139-147.

Tropek, R, Kadlec, T, Hejda, M, Kocarek, P, Skuhrovec, J, Malenovsky, I, Vodka, S, Spitzer, L, Banarh, P \& Konvicka, M 2012 , 'Technical reclamations are wasting the conservation potential of post-mining sites. A case study of black coal spoil dumps', Ecological Engineering, vol. 43, pp. 13-18.

Vindušková, O, Frouz, J 2013, 'Soil carbon accumulation after open-cast coal and oil shale mining in Northern Hemisphere: a quantitative review', Environmental Earth Sciences, vol. 69, pp. 1685-1698.

Wick, AF, Ingram, LJ \& Stahl, PD 2009, 'Aggregate and organic matter dynamics in reclaimed soils as indicated by stable carbon isotopes', Soil Biology and Biochemistry, vol. 41, pp. 201-209. 